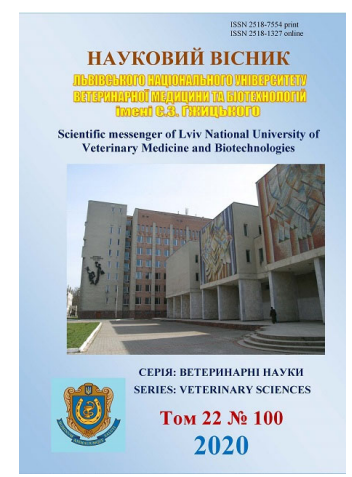

\author{
Науковий вісник Дьвівського націонадьного університету \\ ветеринарної медицини та біотехнологій імені С.3. Гжицького. \\ Серія: Ветеринарні науки \\ Scientific Messenger of Lviv National University \\ of Veterinary Medicine and Biotechnologies. \\ Series: Veterinary sciences
}

UDC 636.2:611-018:591.481.1

\title{
Neuroarchitectonics of the medulla oblongata of cattle
}

O. E. Hohitidze

Odesa Regional State Laboratory of the Civil Service of Ukraine for Food Safety and Consumer Protection, Odesa, Ukraine

Article info

Received 16.10.2020

Received in revised form 16.11.2020

Accepted 17.11.2020

Odesa Regional State Laboratory of the Civil Service of Ukraine for Food Safety and Consumer

Protection, Savranska Str., 4 Odesa, 65000, Ukraine. Tel.: +38-067-489-40-75 E-mail: aleksandrgogitidze@gmail.com
Hohitidze, O. E. (2020). Neuroarchitectonics of the medulla oblongata of cattle. Scientific Messenger of Lviv National University of Veterinary Medicine and Biotechnologies. Series: Veterinary sciences, 22(100), 103-107. doi: 10.32718/nvlvet10018

The article presents data from the study of neuroarchitectonics of the medulla oblongata of cattle. The main attention was paid to the peculiarities of neuronal morphology, determination of their type and prevalence of a certain population of cells in the tissue. The study was performed on 23 brain samples taken from animals aged 2-11 years. To reveal the architectonics of neurons, methods of fabric impregnation with silver were used according to Golgi, Ramon-Kahal and Bolshovsky. The main criteria for determining the type of cells were such features as: cell body size, its shape, number and distribution of processes, their thickness, tortuosity and branching. According to the results, we can identify four main populations of neurons, which are represented by such morphofunctional cell types as: reticular, large polygonal (motor), small round (sensory) and spindle-shaped. The largest population consists of reticular neurons, the second most common are sensory, then motor and the least represented spindle-shaped. It was found that the population of sensory-type neurons includes such structures as the Gracilis and Cutaneus nucleus, the complex of olive inferior nuclei and the nucleus of the solitary tract. Motor are represented respectively in the dorsal, ventral and lateral motor nuclei, the hipoglossy nucleus, the ventral nucleus of the vagus nerve and the ventral subunit of the dorsal nucleus of the vagus nerve. Spindle-shaped neurons are represented only in the dorsal subunit of the dorsal nucleus of the vagus nerve, and reticular form the largest population represented by the reticular formation and the lateral nucleus. A certain pattern of distribution of cell types in the tissue is traced. Thus, the most archaic and architectural - reticular neurons form the center of cell mass, while specialized forms of cells - motor and sensory distributed on the periphery. In a separate type, spindle-shaped neurons of the dorsal nucleus of the vagus nerve are isolated, as cells of the transition link from reticular to motor.

Key words: neuroarchitectonics, neuronal population, morphology of medulla oblongata, neurovs system of cattle.

\section{Нейроархітектоніка довгастого мозку великої рогатої худоби}

\author{
О. Є. Гогітідзе
}

Одеська регіональна Державна лабораторія державної служби Украӥни з питань безпечності харчових продуктів та захисту споживачів, м. Одеса, Україна

У статті наведені дані вивчення нейроархітектоніки довгастого мозку великої рогатої худоби. Основна увага була приділена особливостям морфологї̈ нейронів, визначенню їх типу та розповсюдженості певної популяиї клітин у тканині. Дослідження проводилось на 23 зразках мозку, відібраного від тварин віком 2-11 років. Для виявлення архітектоніки нейронів, застосовувались методи імпрегнації тканини сріблом за Гольджи, Рамон-Кахалем та Більшовським. Основними критеріями визначення типу клітин, слугували такі ознаки як: розмір тіла клітини, його форма, кількість та розподіл відростків, ӥх товщина, звивистість та розгалуженість. Згідно результатів, можна визначити чотири основні популяції нейронів: ретикулярні, великі полігональні (руховi), дрібні округлі (сенсорні) та веретеноподібні. Найбільшу популяцію складають ретикулярні нейрони, другими по розповсюдженню є сенсорні, далі рухові і найменш представлені веретеноподібні. Було встановлено шуо, популяція нейронів сенсорного 
типу охоплює такі структури як ніжне та клиноподібне ядро, комплекс ядер нижньої оліви та ядро солітарного тракту. Рухові (моторні) представлені відповідно у дорсальному, вентральному та латеральному моторних ядрах, ядрі під'язикового нерву, вентральним ядром блукаючого нерву та вентральною субодиницею дорсального ядра блукаючого нерва. Веретеноподібні нейрони представлені тільки у дорсальній субодиниці дорсального ядра блукаючого нерва, а ретикулярні формують найбільшу популячію щзо представлена ретикулярною формаціїею та латеральним ядром. Прослідкована певна закономірність розподілу типів клітин у тканині. Так, найбільш архаічними та архітектонікою - ретикулярні нейрони формують иентр клітинної маси, в той час як спеціалізовані форми клітин - рухові та сенсорні розподілені по періферії. В окремий тип виділені веретеноподібні нейрони дорсального ядра блукаючого нерва, як клітини перехідної ланки від ретикулярних до рухових.

Ключові слова: нейроархітектоніка, нейронні популяиії, морфологія довгастого мозку, нервова система великої рогатої худоби.

\section{Вступ}

Дані про розповсюдження тих, чи інших популяцій нейронів у тканині мозку необхідні для розуміння структури та функції ядерних утворень та формацій тканини, а також вивчення розвитку певних хвороб (Panzeri et al., 2015; Bicanic et al., 2017; Jiang et al., 2020). На сьогодення існує чимало робіт 3 нейроархітектоніки мозку людини та лабораторних тварин (Hirahara et al., 2017; Stepanov \& Akulinin, 2017; Fonseca et al., 2018) але, враховуючи поступове збільшення уваги до морфології центральної нервової системи великої рогатої худоби, є необхідність отримання знань $з$ особливості морфології головного мозку цих тварин.

Більшість робіт, які присвячені морфології нервової системи великої рогатої худоби, засновані на анатомічних та гістологічних дослідженнях, із застосуванням методів вивчення цитоархітектоніки тканини, які є доволі інформативними щодо загальної організації клітинних утворювань, але не дають змогу визначити особливості арборізації нейронів - принципової ознаки належності клітини до того, чи іншого типу (Meshherjakov \& Mihajlov, 2006; Ballarin et al., 2016; Guerrero et al., 2020). Навіть, коли застосовується методика виявлення архітектоніки нейронів отримана інформація, в основному, подається як опис окремих клітин, без спроб іiї аналізу (Horalskyi, 2014; Horalsky et al., 2018).

Mета статті дослідити особливості розподілення нейронів різних типів в тканині довгастого мозку та спроби надання визначеним фактам певного теоретичного обгрунтування.

\section{Матеріал і методи досліджень}

Дослідження виконувалось на базі Одеської регіональної Державної лабораторії державної служби України з питань безпечності харчових продуктів та захисту споживачів. Матеріалом слугувало 23 зразка довгастого мозку, відібраних після забою у тварин віком 2-11 років. Для імпрегнації нейронів застосовували методики за Гольджи у модифікації Бюбенета, за Рамон-Кахалем та Більшовським. В залежності від методики, імпрегнацію проводили у шматочках (Гольджи, Рамон-Кахаль ), або на зрізах (Більшовський). Мікрофотографування робили під мікроскопом Nikon Eclipse E200, за допомогою фотокамери Nikon D 60. Морфометричну обробку зображень проводили у програмі Image J. Ураховуючи різноманіття структур, опис здійснювали за певними ділянками: ділянка дорсальних канатиків, ділянка трикутників та ділянка вестибулярного підняття.

\section{Результати та їх обговорення}

На всіх рівнях дослідження, нейрони ядерних утворень та формації, за морфологічними ознаками можна розподілити на чотири типа:

1. Округлі, дрібні (8-20 мкм) нейрони сенсорного типу з 3-8 відростками. Відростки звивисті, малогілчасті, по віддаленню від тіла клітини поступово потоншуються. Дендритне дерево розповсюджується навколо клітини, утворюючи сферичне поле, яке дорівнює 3-6 діаметрам тіла клітини. Аксональний горбок визначається слабо. Клітини такого типу визначені у ніжному та клиноподібному ядрах (NG, NC), низхідному ядрі трійчастого нерва (NSnT) та ядрах нижньої оліви: дорсальному, основному та вентральному (Old, Ol, Olv) (рис. 1).

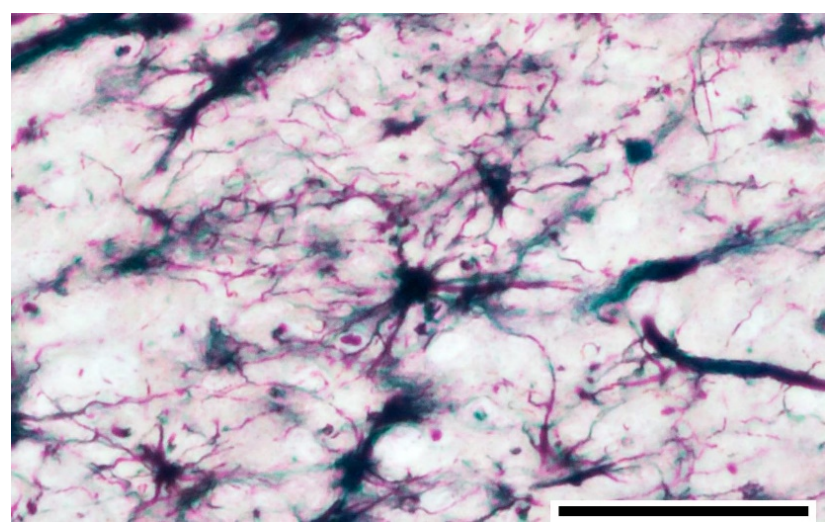

Рис. 1. Нейрони сенсорного типу дорсального рогу на рівні дорсальних канатиків. Гольджи. - 100 мкм

2. Видовжені (веретеноподібні), середнього розміру клітини (25-50 мкм), які мають доволі виразний, полюсний аксональний горбик 3 виступаючим 3 нього помітним аксоном та дендрити, які відходять від тіла клітини по всій іiі поверхні в кількості 47 гілок. Ці клітини визначені у дорсальному ядрі блукаючого нерва (NVD) та на периферії низхідного ядра трійчастого нерва (рис. 2).

3. Полігональні нейрони ретикулярного типу, доволі крупні (40-70 мкм), 3 помірно видовженим тілом, від якого відходять небагаточисленні відростки, що мають широку основу та в подальшому поступово звужуються. Відростки крупнозвивисті середньоветвисті. Ці клітини складають основу ретикулярній формації та ії ядер, найкрупніше з яких латеральне ядро (NL) (рис. 3). 


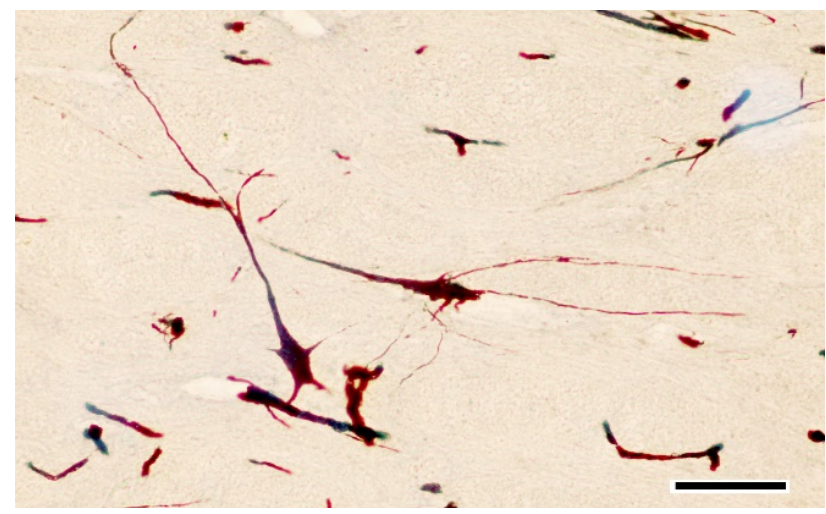

Рис. 2. Веретеноподібні нейрони середньої частини сірої речовини на рівні дорсальних канатиків. Гольджи. -100 мкм

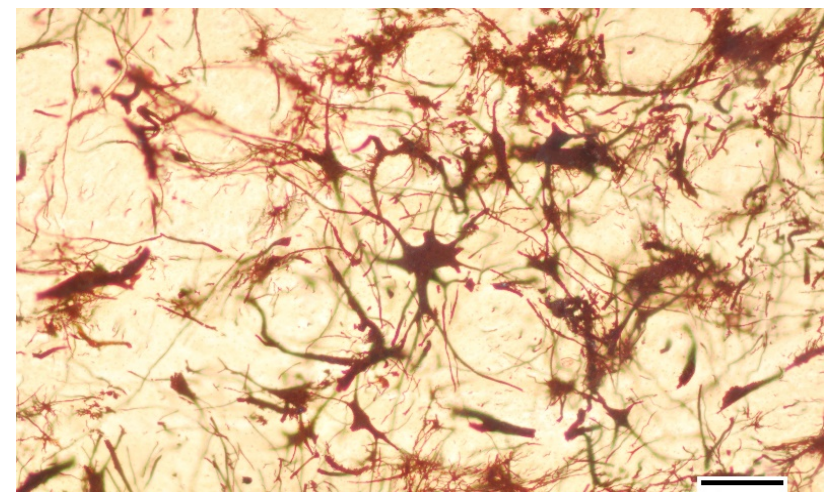

Рис. 3. Полігональний нейрон ретикулярного типу. Ретикулярна формація. Гольджи. -100 мкм

4. Полігональні нейрони рухового типу. Це найкрупніші нейрони довгастого мозку (52-94 мкм), які мають 3-5 великих, практично прямих, нерозгалужених, рівних за товщиною на всьому своєму протязі відростка, які значні за довжиною і зазвичай повністю в зріз не потрапляють. 3 таких клітин побудовані рухові ядра: під’язикове (NH), вентральна субодиниця дорсального ядра блукючого нерва та вентральне ядро блукаючого нерва (NVV) (рис. 4).

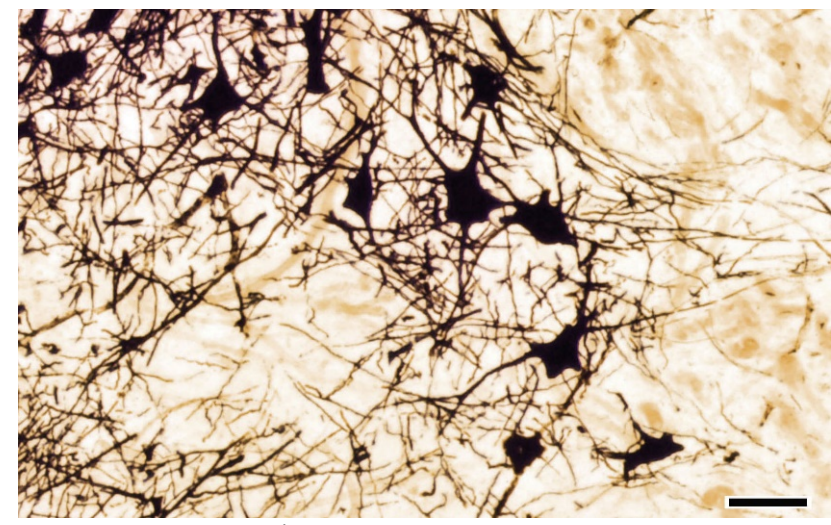

Рис. 1. Полігональний нейрон рухового типу.

Гольджи. - 100 мкм

Розподіл клітин за ділянками. На рівні дорсальних канатиків, всі чотири типи клітин займають майже однакову площу: сенсорні - в ділянці желатинозної субстанції, при цьому клітини розподілені пошарово, паралельно дорзолатеральній межі желатинозної суб- станції. Веретиноподібні нейрони займають медіальну частину середньої ділянки сірої речовини і незначно входять до дорсального рогу, в зоні розташування клиноподібного ядра. Полігональні ретикулярні нейрони розташовані у латеральній частині центральної ділянки сірої речовини. Полігональні рухові нейрони формують весь вентральний ріг. Слід зазначити, що чітко відмежованими є тільки моторні ядра вентрального рогу (NMD. NMV, NMM). В полі веретеноподібних нейронів, біля центрального каналу, в окремих препаратах, можна визначити на цьому рівні скупчення клітин, які в краніальному напрямку дають, в подальшому, дорсальне ядро блукаючого нерва (NVD). Відокремленним є також ніжне ядро (NG), яке займає дорзомедіальну частину препарату і має, на цьому рівні доволі незначну фронтальну площу (рис. 5).

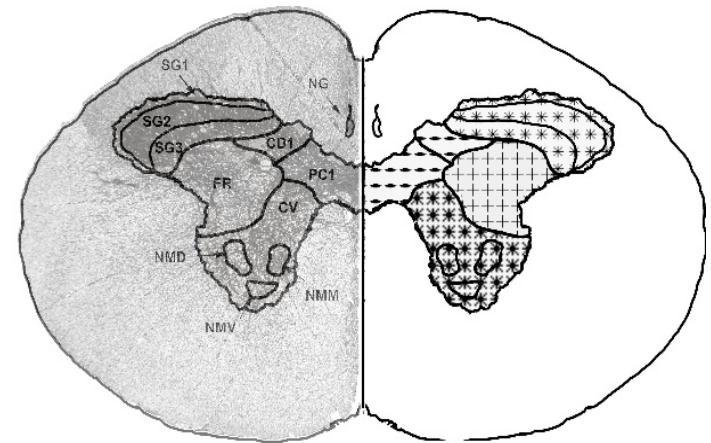

Рис. 2. Проекція поля нейронів сенсорного (*), веретеноподібного (-), ретикулярного $(+)$ та рухового $(*)$ типу на рівні дорсальних канатиків. -5 мм

Ділянка затулки. Спостерігається розділення нейронних полей на окремі ділянки, відповідно до певних формації і ядер. Нейрони сенсорного типу формують ніжне та клиноподібне ядра, при цьому їх площа займає практично всю дорсальну частину сірої речовини, низхідне ядро трійчастого нерва та спостерігаються у основному, та додатковому дорсальному ядрах олів (Ol, Old). Площа веретеноподібних нейронів значно зменшилась і спостерігати їх можна лише у дорсальному ядрі блукаючого нерва (NVD). Нейрони ретикулярного типу, формують значне поле ретикулярної формації і значне за розмірами латеральне ядро (NL). Рухові нейрони відокремились у два ядра: під'язикове (NH) та вентральне ядро блукаючого нерва (NVV) (рис. 6).

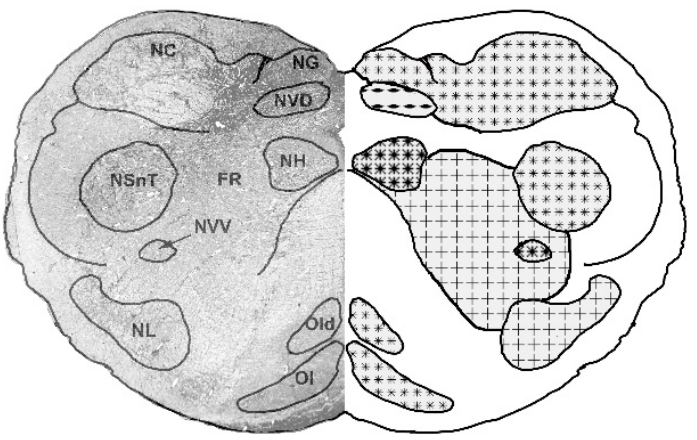

Рис. 3. Проекція поля нейронів сенсорного (*), веретеноподібного (-), ретикулярного $(+)$ та рухового $(*)$ типу, на рівні затулки. -5 мм 
Ділянка трикутників 1. Поле рухових нейронів розширюється завдяки появі їх у вентральній частині дорсального ядра блукаючого нерва та збільшенню ядра під'язикового нерва. Ділянка сенсорних нейронів зменшується, внаслідок зменшення площі ніжного та клиноподібного ядер та ядер нижньої оліви, але при цьому, з'являється дрібне ядро солітарного тракту (TS), яке також побудоване 3 нейронів сенсорного типу. Значно розширюється поле ретикулярної формації (рис. 7).

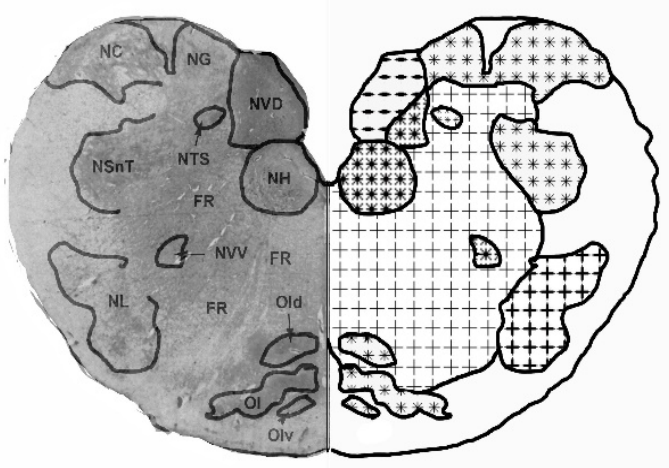

Рис. 4. Проекція поля нейронів сенсорного (*), веретеноподібного (-), ретикулярного $(+)$ та рухового $(*)$ типу в ділянці трикутників 1. -5 мм

Ділянка трикутників 2. Розподіл та площа полей залишається практично такою ж, за виключенням збільшення ділянки рухових нейронів у дорсальному ядрі блукаючого нерва (рис. 8).

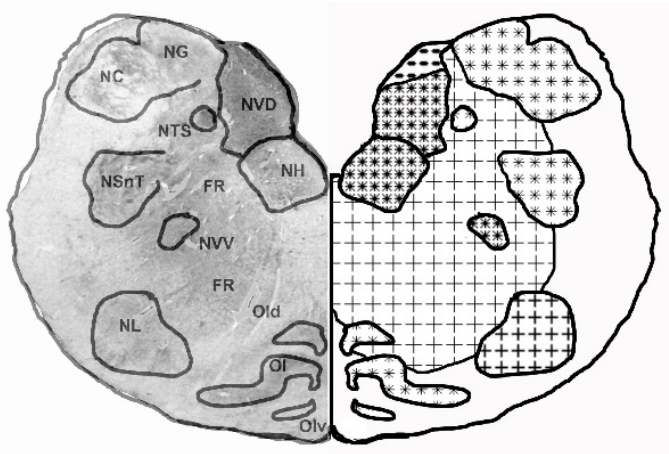

Рис. 5. Проекція поля нейронів сенсорного (*), веретеноподібного (-), ретикулярного (+) та рухового (*) типу в ділянці трикутників 2.

Ділянка трикутників 3. Дорсальне ядро блукаючого нерва повністю виконане нейронами рухового типу. Обидва рухових ядра: ядро під’язикового нерву та дорсальне ядро блукаючого нерву значно зменшуються. Розміри вентрального ядра блукаючого нерва збільшуються. Також збільшується поле ретикулярної формації. Зникає вентральне додаткове ядро нижньої оліви (рис. 9).

Ділянка вестибулярного підняття 1. Продовжується зменшення поля рухових нейронів - зменшенням ядра під'язикового нерва, дорсального та вентрального ядра блукаючого нерва. 3'являється ядро лицевого нерва (NF), яке також побудоване 3 полігональних рухових нейронів, але його площа невелика (рис. 10).

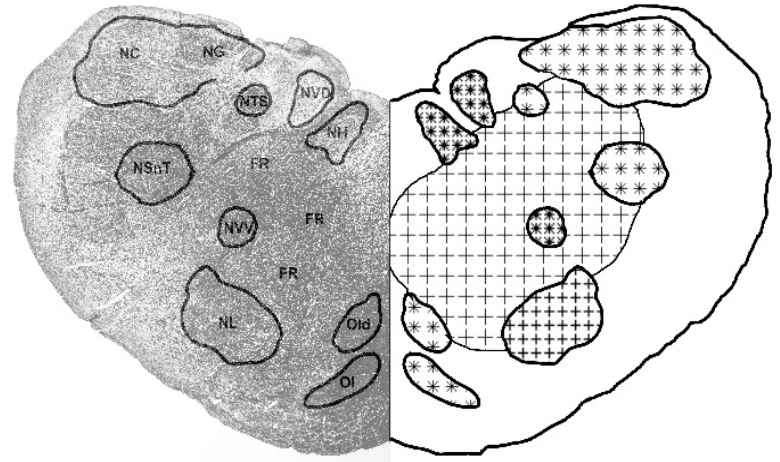

Рис. 6. Проекція поля нейронів сенсорного (*), веретеноподібного (-), ретикулярного (+) та рухового (*) типу в ділянці трикутників 3. -5 мм

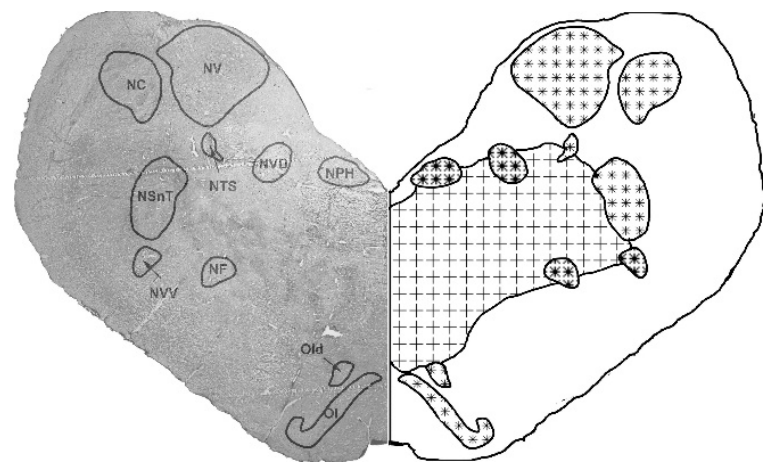

Рис. 7. Проекція поля нейронів сенсорного (*), веретеноподібного (-), ретикулярного (+) та рухового (+) типу, в ділянці вестибулярного підняття

Аналіз отриманих результатів показує що, нейрони сенсорного типу розподілені у тканині по структуpax, які $є$ колекторами у передачі нервових імпульсів з зовнішніх аналізаторів, до центрів стовбуру, гіпоталамусу та мозочка. Ядра дорсальних канатиків ніжне та клиноподібне, сприймають подразнення від нейронів спинномозкових вузлів i, формуючи внутрішню петлю та мотузкове тіло, спрямовують їх вже у зміненому вигляді до ядер гіпоталамусу та мозочка. Низхідне ядро трійчастого нерву є другою ланкою зовнішньої чутливості для шкіри голови а оліви - третьою для шкірно-м'язового аналізатора тулуба. Цікаво, що схожою будовою визначається і ядро солітарного тракта - сенсорного центру блукаючого нерва.

Доволі різко виділені нейрони рухового типу. Їх розташування у ядрі під'язикового нерва, дорсальному та вентральному ядрі блукаючого нерва, цілком пояснюється природою цих центрів - рух скелетних та гладких м'язів. Окремо виділяються веретеноподібні клітини. Вони зустрічаються поряд з нейронами рухового типу у дорсальному ядрі блукаючого нерва i при тому, формують виразну його субодиницю.

Нейрони ретикулярного типу мають саме широке представництво у довгастому мозку i, відповідно, формують ретикулярну субстанцію з ії ядрами, найбільше з яких - латеральне.

Найбільший об'єм в тканині займає поле ретикулярних нейронів, трохи менший нейрони сенсорного типу, далі нейрони рухового типу і найменший - доволі спеціалізовані веретеноподібні. 
Слід сказати що, прослідковується певна локальна прив'язка типів нейронів до ділянки тканини. Так, більш архаїчні нейрони - ретикулярного типу займають центральне положення, тоді як спеціалізовані форми нейронів - сенсорні і рухові, зміщені до периферії при цьому, саму крайову позицію займають сенсорні, а рухові - проміжну.

\section{Висновки}

За нейроархітектонікою, довгастий мозок великої рогатої худоби можна віднести до ретикулярносенсорного типу. В ньому найбільш розвинуті структури регуляції основних, базових функцій життєдіяльності (дихання, серцебиття, підтримання загального тонусу скелетних м'язів) та центри сприймання зовнішніх і внутрішніх подразнень шкіри та м'язів тулуба і голови.

\section{References}

Horalskyi, L. P. (2014). Morfolohiia orhaniv nervovoi systemy velykoi rohatoi khudoby. Problemy zooinzhenerii ta veterynarnoi medytsyny, 28, 362-367 (in Ukrainian).

Horalsky, L., Sokulsky, I., Kolesnik, N., Demus, N., \& Solimchuk, V. (2018). Morphological features of cerebellum in cattle. Scientific Messenger of LNU of Veterinary Medicine and Biotechnologies. Series: Veterinary Sciences, 20(83), 125-129. doi: $10.15421 /$ nvlvet8324.

Meshherjakov, F. A., \& Mihajlov, M. (2006). Stereotaksicheskie dannye ventral'noj oblasti golovnogo mozga u krupnogo rogatogo skota. Vestnik Veterinarii, 3(38), 64-67. URL: https://www.elibrary.ru/ item.asp? $\mathrm{id}=11600698$ (in Russian).

Stepanov, A. S., \& Akulinin, V. A. (2017). Osobennosti morfometricheskogo izuchenija citoarhitektoniki neokorteksa cheloveka pri immunogistohimicheskoj vizualizacii neun i map-2. Sovremennyj problemy nauki i obrazovanija, 2, 65-73. URL: https://www.scienceeducation.ru/ru/article/view?id=26266 (in Russian).

Ballarin, C., Povinelli, M., Granato, A., Panin, M., Corain, L., Peruffo, A., \& Cozzi, B. (2016). The Brain of the Domestic Bos taurus: Weight, Encephalization and Cerebellar Quotients, and Comparison with Other Domestic and Wild Cetartiodactyla. Plos One, 4(11), e0154580. doi: 10.1371/journal.pone.0154580.
Bicanic, I., Hladnik, A., \& Petanjek, Z. (2017). A Quantitative Golgi Study of Dendritic Morphology in the Mice Striatal Medium Spiny Neurons. Frontiers in Neuroanatomy, 11, 37. doi: 10.3389/fnana.2017.00037.

Fonseca, M. d. C., Araujo, B. H. S., Dias, C. S. B. et al. (2018). High-resolution synchrotron-based X-ray microtomography as a tool to unveil the threedimensional neuronal architecture of the brain. Sci Rep, 8, 12074. doi: 10.1038/s41598-018-30501-X.

Guerrero, M. Veuthey, C., del Sol, M., \& Ottone, N. E. (2020). Dissection of white matter association fasciculi in bovine (Bos taurus), pig (Sus scrofa domesticus) and rabbit (Oryctolagus cuniculus) brains. Anatomia Histologia Embryologia, 4(49), 550-562. doi: 10.1111/ahe.12561.

Hirahara, M., Fujiwara, N., \& Seo, K. (2017). Novel trigeminal slice preparation method for studying mechanisms of nociception transmission. Journal of Neuroscience Methods, 286, 6-15. doi: 10.1016/j.jneumeth.2017.05.019.

Jiang, X. Saggar, H., Ryu, S. I., Shenoy, K. V., \& Kao, J. C. (2020). Structure in Neural Activity during Observed and Executed Movements Is Shared at the Neural Population Level, Not in Single Neurons. Cell Reports, 6(32), 108006. doi: 10.1016/j.celrep.2020.108006.

Kartalou G.-I., Endres, T., Lessmann, V., \& Gottmann, K. (2020). Golgi-Cox impregnation combined with fluorescence staining of amyloid plaques reveals local spine loss in an Alzheimer mouse model. Journal of Neuroscience Methods, 341, 108797. doi: 10.1016/j.jneumeth.2020.108797.

Kassem M. S. Fok, S. Y. Y., Smith, K. L., Kuligowski, M., Balleine, B. W. (2018). A novel, modernized Golgi-Cox stain optimized for CLARITY cleared tissue. Journal of Neuroscience Methods, 294, 102-110. doi: 10.1016/j.jneumeth.2017.11.010.

Panzeri, S. Macke, J. H., Gross, J., \& Kayser, C. (2015). Neural population coding: combining insights from microscopic and mass signals. Trends in Cognitive Sciences, 3(19), 162-172. doi: 10.1016/j.tics.2015.01.002.

Reberger R. Dall'Oglio, A., Jung, C. R., Rasia-Filho, A. A. (2018). Structure and diversity of human dendritic spines evidenced by a new three-dimensional reconstruction procedure for Golgi staining and light microscopy. Journal of Neuroscience Methods, 293, 2736. doi: 10.1016/j.jneumeth.2017.09.001. 